\title{
DATA FORGERY DALAM PERKAWINAN DINI PERSPEKTIF FUNGSIONALISME STRUCTURAL
}

\author{
ST. Sariroh \\ UIN Kiai Haji Achmad Siddiq Jember \\ iera.sariroh@gmail.com
}

\begin{abstract}
Abstrak
Perkawinan dini bukan hal tabu dilakukan di Madura. Banyak pasangan menikah diusia muda. Dalam Undang-undang perkawinan No. 16 Tahun 2019 bahwa perkawinan bisa terlaksanan jika mempelai sudah berusia 19 tahun. Namun mereka cenderung menambahkan usia dalam identitas perkawinan tanpa memohon dispensasi nikah. Ini dilakukan untuk menghilangkan rasa maloh atau tade' ajbinah di masyarakat yang disebabkan Marriage by Accident dan mendapatkan legalisasi hukum. Dari permasalahan tersebut akan dianalisa bagaimana fenomena data forgery dalam pernikahan dini perspektif Fungsionalisme Struktural? Penelitian ini mengguakan pendekatan kualitatif dengan studi kasus, perolehan data menggunakan metode interview, observasi dan documentasi. Hasil penelitian; 1). Perkawinan dini dilaksanakan oleh pasangan "sebelum usia 19 tahun ". Dengan cara menambahkan usia di identitas perkawinanya sebab Marriage by Accident, karena menjadi beban keluarga yang dapat menimbulkan rasa maloh atau tade' ajbinah. 2). Fungsionalisme struktural data forgery dalam perkawinan dini; Adaptation; proses habituasi para aktor dengan sistem sosial di masyarakat adalah dengan cara memalsukan usia perkawinan. Goal Attainment; hal ini demi mendapatkan legalisasi hukum perkawinan dan meningkatkan harkat martabat keluarga menjadi lebih baik. Integration; tidak selarasnya fungsi sistem sosial dan struktur lembaga di KUA. Latency; Masyarakat harus memelihara pola-pola tradisi sebaik mungkin, seperti penghormatan dan kepatuhan terhadap harga diri keluarga maupun orang lain.
\end{abstract}

Kata Kunci: Data Forgery, Perkawinan Dini, Fungsionalisme Struktural

\begin{abstract}
Early marriage has accustomed in Madura. In act 16 in 2019 explained that marriage can be implemented if both of bride have 19 years old. Whereas, they add the age in their marriage certificate without asking marriage dispensation to religious court. This carried out to diminish malo and tade' ajhinah in social environment caused of Marriage by Accident and get legal marriage. From the problem above will describe how is the Early marriage happened in Madura in Structural Functionalism perspective?. This research using qualitative approache and case study. The data collected by using interview, observation, documentation. The result; 1). The early marriage performed by young couple "under 19 years old "by adding the age in marriage certificate because of pregnant, it becomes moral burden which cause shamed and tade' ajhinah. 2). structural functionalism of Early marriage, Adaptation; adaptation process of the actor to the social system i.e. married by adding the age. Goal-Attainment; This marriage
\end{abstract}




\section{ST. Sariroh}

aims to get registered marriage and to improve the family dignity. Integration; disintegration between social system and organizational structure. Latency; Madurese must maintain and sustain well-regarded cultural patterns such as their obedience and the reverence both of their own dignity and others.

Keywords: Data Forgery, Early Marriage, Structural Functional

\section{Pendahuluan}

Perkawinan dini bukanlah persolan baru di masyarakat Madura. Di Sumenep, tradisi yang masih ada yaitu mengawinkan anaknya yang belum baligh/dewasa. Perempuan menikah diusia yang sangat muda kisaran usia 9-15 tahun dan usia 12-20 tahun bagi pria. ${ }^{1}$ angka perkawinan di usia dini menurut Data Program Informasi Konseling Reproduksi Remaja (PIK-KRR) meningkat drastis di Madura. Menurut Nunuk Lestari kepala BKKBN Jawa Timur, "pernikahan dini terjadi disetiap kabupaten di Madura yaitu Bangkala, Sumenep, Pamekasan, dan Sampang.

Dalam Undang-Undang No. 16 Tahun 2019 tentang perubahan terhadap UU Perkawinan no. 1 tahun 1974, dalam pasal 1 terkait ketentuan perubahan dari pasal 7 undang-undang no. 1 tahun 1974, menjelaskan bahwa Perkawinan hanya diizinkan apabila pria dan wanita sudah mencapai umur 19 (sembilan belas) tahun. Secara eksplisit dijelaskan bahwa perkawinan

${ }^{1}$ Yudho Bawono dan Suryanto, "Does Early Marriage Make Women Happy?a Phenomenological Finding from Madurese Women", Journal of Educational, Health and Community Psychology, Vol 8, No 1, (2019), 85, http://dx.doi.org/10.12928/jehcp.v8i1.12197 hanya bisa dilaksanakan jika kedua mempelai sudah berusia 19 tahun. $^{2}$

Selanjutnya dalam pasal 1 ayat (2) Undang-Undang No. 16 Tahun 2019 dijelskan bahwa jika terjadi penyimpangan terhadap ketentuan usia sebagaimana dimaksud pada ayat (1) diatas, orang tua pihak pria dan/atau orang tua pihak wanita dapat meminta dispensasi kepada Pengadilan dengan alasan sangat mendesak disertai buktibukti pendukung yang cukup. ${ }^{3}$ Dispensasi nikah ini disyaratkan untuk diajukan ketika usia mempelai tidak memenuhi batas umur dalam pelaksanaan pernikahan.

Dalam kasus belum terpenuhinya usia perkawinan anak tidak jarang para orangtua menambahkan atau memalsukan usia perkawinan dalam surat keterangan pelaksanaan tersebut. Hal ini banyak terjadi di masyarkat Madura khususnya di kabupaten Sumenep, mereka tidak mau melalui proses pengajuan dispensasi nikah ke Pengadilan Agama, namun lebih memilih menambahkan usia pada keterangan calon pengantin tersebut.

${ }^{2}$ Undang-Undang No. 16 Tahun 2019 Tentang Perubahan Terbadap UU Perkawinan no. 1 tabun 1974, 2 ${ }^{3}$ Undang-Undang No. 16 Tahun 2019 Tentang Perubahan Terbadap UU Perkawinan no. 1 tahun 1974, 3 
Pernikahan dini dilaksanakan dengan yaitu menambah umur dalam lembar keterangan perkawinan agar proses pelaksanaan perkawinan segera terlaksana, karena mereka tidak mau menunggu lama hanya karena proses dispensasi. Sehingga dengan hal ini, mereka bisa langsung melaksanakan perkawinan di KUA (Kantor Urusan Agama) dengan lancar dan legal. Penambahan atau pemalsuan data usia ini sudah mendapatkan persetujuan melalui kesepakatan antara pihak KUA dan Mudin Desa. Kajian tentang penikahan dini memang sudah banyak dilakukan, namun penulis membahas lebih dalam kasus data forgery dalam pelaksanaan pernikahan dini prespektif Fungsionalisme Structural Talcoot Parson. Dengan menelaah lebih dalam tentang proses dan managemen terlaksananya pernikahan dibawah usia tanpa melalu dispensasi perkawinan sehingga menjadi pernikahan yang legal dan sah menurut undang-undang negara.

Untuk membuktikan kebenaran terhadap realitas sosial ini penulis akan menerapkan teori sosiologi yaitu Fungsionalisme Struktural dalam menelaah lebih dalam. Pencetus teori ini adalah tokoh “sosiolog profesional” yaitu Talcott Parsons yang dilahirkan di Colorado Spring. Dengan Teori akan dikaji tentang function of the structure dan perbuatan tingkahlaku manusia dalam suatu lingkungan dan menelaah bentuk hubungan dengan elemen-elemen lain untuk menumbuhkan suasana damai serta ketentraman di lingkungan sosial.

Menurut kajian teori ini suatu kelompok individu adalah sebuah struktur yang dikendalikan oleh system, dimana setiap komponen harus saling berintegrasi dengan fungsi-fungsi yang lain. Semua struktur dan komponen tersebut harus terlaksana secara imbang dan baik. Jika terjadi ketimpangan yang disebabkan oleh salah satu komponen maka dikemudian hari akan timbul masalah serta ketidakrukunan yang berimbas terhadap kehidupan yang tidak stabil dan buruk.

Ada beberapa persyaratan yang harus terpenuhi dalam teori Fungsionalisme Struktural agar semua system sosial berjalan seimbang dan saling terintegrasi. Talcoot Parson mengembangkan imperatif-imperatif fungsional agar saling berhubungan dan terintegrasi yaitu yang biasa disingkat dengan nama AGIL: Adaptation, Goal-Attainment, Integration, dan Latency. ${ }^{4}$

Tujuan penulisan penelitian ini adalah untuk mendeskripsikan bagaimana fenomena

${ }^{4}$ St. Sariroh, 'Perkawinan Dini Perspektif Fungsionalisme Struktural Talcoot Parsons: studi kasus di Desa Poreh Kecamatan Lenteng kabupaen Sumenep'. Thesis. (UIN-Malang: 2017), 8. Lihat dalam Talcott Parsons, The Social system, Edisi Ke-II (New York: The Free Press, 1951), xviii 


\section{ST. Sariroh}

perkawinan dini yang terjadi di Madura yang kemudian akan dianalisa menggunakan teori Fungsionalisme Struktural Talcoot Parson.

\section{Metodologi Penelitian}

Penelitian ini menggunakan pendekatan kualitatif-deskriptif dengan studi kasus. Tujuan penelitian kualitatif dalam penelitian ini adalah untuk memperoleh pemahaman yang mendalam ${ }^{5}$ tentang permasalahan perkawinan dini yang terjadi di Madura.

Teknik pengumpulan data dalam penelitian ini menggunakan interview, observasi dan dokumentasi. Metode interview yang digunakan adalah semi terstruktur yaitu dengan cara ngobrol santai, dimana pihak yang diajak wawancara dimintai pendapat, dan ide-idenya ${ }^{6}$. Hal ini dilakukan oleh peneliti agar pihak yang diajak wawancara lebih terbuka dan bercerita tentang permasalahan yang terjadi. Kemudian dilakukan analisa menggunakan teori fungsionalisme structural yang dicetuskan oleh Talcott parson untuk melihat fenomena yang terjadi dalam aspek sistem sosial dan tingkahlaku aktor dalam fenomena data forgery perkawinan dini lebih mendalam.

5 Ismail Nurdin dan Sri Hartati, Metode Penelitian Sosial. (Surabaya: Media Sahabat Cendekia, 2019), 41

${ }^{6}$ Sugiyono, metode penelitian pendidikan kuantitatif, kualitatif dan R dan D, (Bandung: Alfa Beta, 2013), 233

\section{Hasil Penelitian dan Pembahasan}

\section{Fenomena Perkawinan Dini}

Fenomena perkawinan dini ini sampai saat ini masih banyak terkadi dikalangan masyarakat Madura. Banyak diantara mereka menikahkan putra atau putrinya di usia muda bahkan ketika masih didalam kandungan sudah dijodohkan. Proses penjodohan ini harus dilakukan sebelum terjadi perkawinan baik dilakukan oleh pertemanan keluarga, namun banyak juga yang dilakukan oleh kerabat sendiri, seperti perjodohan saudara sepupu dan sebagaianya.

Masyarakat Madura dikenal sangat kental dengan adat istiadat yang diwarisi oleh nenek moyang mereka. Seperti tradisi perjodohan dan pernikahan diusia muda. ${ }^{7}$

Sosial budaya seperti ini masih sulit dihilangkan dibeberapa lingkungan masyarakat tertentu terlebih di masyarakat pedesaan, hal ini disebabkan karena ketaatan mereka terhadap pendahulunya yang masih kuat. Kebiasaan ini demi menjaga kehormatan keluarga jika anaknya yang menurut mereka dianggap dewasa belum berjodoh. Tradisi pendahulu-pendahulu terbiasa menikahkan putrinya setelah mengalami "menstruasi" yaitu kisaran usia

${ }^{7}$ Ainur Mila Rofika dan Iswari Hariastuti, "Faktor Sosial Budaya yang Mempengaruhi Terjadinya Pernikahan pada Usia Anak di Kabupaten Sumenep", Jurnal Promkes: The Indonesian Journal of Health Promotion and Health Education, Vol. 8 No. 1 (2020), 13, http://dx.doi.org/10.20473/jpk.V8.I1.2020.12-20 
12-15 Tahun. ${ }^{8}$ Jika lewat dari usia tersebut dan masih tak kunjung berjodoh mereka bisa mendapat cemooh atau gunjingan sebagai wanita "tak pajub lakeb" (tidak laku).

Setelah melalui berbagai perkembangan tingkahlaku masyarakat terjadinya pernikahan dini tidak lagi disebabkan oleh tradisi dan ekonomi melainkan ada beberapa factor perubahan sosial yaitu modernisme yang memperngaruhi pergaulan remaja akhir-akhir ini. Tingakah laku atau perbuatan remaja yang menonjol yaitu berdampak negatif yang menjadikan mereka terperangkap dalam tindakan terlarang seperti zina, perbuatan ini jelas melanggar norma sosial, agama dan hukum. Kurangnya kasih sayang dan perhatian dari keluarga juga menjadi salah satu sebab terjerumusnya seorang anak kedalam perbuatan maksiat seperti seks diluar nikah. ${ }^{10}$ Jadi peran keluarga sangat penting dalam mendidik anak demi mencegah konflik sosial, dalam keluarga anak bisa belajar nilainilai moral. ${ }^{11}$

\footnotetext{
${ }^{8}$ Yudho Bawono dan Suryanto, "Does Early Marriage Make Women Happy?a Phenomenological Finding from Madurese Women", 85

'Yudho Bawono, "Low Education And Erly Marriage In Madura: Literature Review", The Journal Of Educational Development, 7 (3) (2019), 170

10Jamilah dan Roudlotun, "Fenomena Pernikahan Anak Di Suemnep Madura", Jurnal Harkat: Media Dan Komunikasi Gender 15 (1) (2019), 37-39, 10.15408/harkat.v15i1.13437.

${ }^{11}$ Rusli, "The Role of Family in Preventing Social Conflict in Society from Islamic Perspectives", Jurnal Hunafa: Studia Islamika, Vol. 17, No. 1, (2020), 116, https://doi.org/10.24239/jsi.v17i1.576.104-118
}

Perilaku ini menjadikan harkat dan martabat keluarga buruk dan jatuh dikalangan masyarkat. sehingga orangtua tidak ada cara lain selain menikahnkan anak mereka meskipun usianya tidak masuk dalam syarat dibolehkannya menikah menurut peraturan yang sah. Hal ini dilakukan demi menjaga status anak yang akan dilahirkan oleh pasangan muda tersebut dan demi menghilangkan perasaan maloh atau tade" ajbinah.

Kapasitas diri seseorang dalam struktur dan system sosial tidak terlepas dari "social rule and status" lebih-lebih bagi orang Madura. Dalam praktik kehidupan masyarakat status sosial ini butuh pengakuan dari lingkungan sosialnya. Sehingga jika terjadi perlakuan tidak dihargai sama halnya dengan diperlakukan sebagai orang yang ' $t a d a$ ' abjinab" (tidak mempunyai martabat sebagai manusia di masyarakat), hal ini yang menimbulkan perasaan malo. ${ }^{12}$

Pelecehan dan bentuk cemooh merendahkan martabat keluarga bisa diakibatkan dari perbuatan tidak senonoh anggota keluarga seperti perbuatan anak-anak mereka yang melanggar norma-norma sosial, agama, dan hukum yang menjatuhkan dalam perbuatan zina. Perbuatan tersebut merupakan hal yang sangat dilarang dalam

${ }^{12}$ A. Latief Wiyata, Mencari Madura, Jakarta : Bidik-Phronesis Publishing, 2013), 23 


\section{ST. Sariroh}

islam. Bagi orang madura yang dikenal dengan sikap ketaatannya terhadap ajaran agama. Lebih-lebih bagi orangtua, beban moral yang ditanggung dapat menimbulkan rasa malo atau tade' ajhinah karena adanya omongan-omongan atau sindiran jelek dari masyarakat bahkan dari sanak keluarga sendiri. Sebagai orang tua mereka merasa tidak berhasil mengajarkan anaknya dengan baik. Karena keadaan tersebut mereka bisa melakukan apa saja demi memperbaiki atau mengurangi beban moral demi menjaga hargadiri keluarganya. Seringkali tindakan perlawanan tersebut cenderung sangat keras bahkan bisa sampai terjadi pembunuhan.

Tindakan perlawanan dari perbuatan tak senonoh yang melanggar norma agama maupun sosial yang dialami oleh salah satu keluarganya seperti terjadinya hamil diluar nikah yaitu dengan cara langsung menikahkannya walaupun usia anaknya belum memenuhi syarat untuk melangsungkan perkawinan secara legal. Namun bagaimanapun caranya perkawinan tersebut harus terlaksana meskipun harus menyalahi aturan negara, yaitu dengan cara memalsukan data usia anak yang akan melangsungkan pernikahan. Selain itu, mereka juga tidak memahami peraturan tentang syarat usia dalam perkawinan, serta beratnya biaya yang akan dibayar dalam proses pengajuan dispensasi nikah. Karena keingin kuat untuk sesegera mungkin untuk melangsungkan perkawinan mereka tidak sabar melalu proses perizinan yang cukup lama.

Selain itu, alasan pemalsuan atau penambahan usia nikah ini karena tidak ingin anaknya melahirkan tanpa seorang suami. Hal tersebut menyebabkan harga diri kelurga semakin buruk dimata masyarakat. Pandangan buruk tersebut tidak mudah hilang begitu saja di masyarakat, apalagi hasil anak yang telah dilahirkan. Ketika dewasa kelak bisa saja dia akan dibuli oleh lingkungan sekitarnya, bahkan sampai ia akan kesulitan untuk memilih jodoh atau pasangan ketika hendak menikah.

Pelanggaran perundangan perkawinan yang dilakuakan orangtua Orang tua sejatinya memiliki tujuan baik bagi keluarga dan juga ada hal-hal keadaan ang menekan untuk berbuat hal tersebut, diantaranya adalah desakan keaadaan yang dihadapi yang membuat mereka merasa maloh dan tade" aajhinah, yang membuat merasa terbebani terhadap hinaan jelek tersebut.

Tinadakan seseorang dalam msyarakat sangat dipengaruhi oleh Lingkungan sosial demi tercapainya suatu tujuan. Dalam teori tindakan Voluntaristic, Talcoot Parsons memahami bahwa seseorang tidak akan bertindak tanpa tujuan yang jelas. Tujuan ini adalah semua keadaan kongkret demi tercapainya apa yang diinginkan. Untuk mencapai suatu harapan tersebut manusia 
dapat dipengaruhi oleh bermacam-macam faktor salah satunya yaitu, sistem sosial atau kebiasaan dalam kehidupan masyarakat yang akan dihadapi. Seperti perlakuan pemalsuan data usia anak dalam perkawinan yaitu demi cepatnya proses pernikahan yang akan berlangsung demi memperoleh hak yang lega secara hukum.

Selain itu karena ketidak pahaman mereka terhadap peraturan perundangan yang berlaku. Memang mayoritas data tingkat pendidikan masyarakat di Sumenep hanya lulusan sekolah dasar/ madrasah ibtidaiyah, dan banyak juga diantara mereka hanya menempuh pendidikan non formal seperti di pondok-pondok salaf, dimana mereka hanya memperoleh pelajaran ilmu-ilmu agama. Tindakan pelanggaran terhadap peraturan perundangan terhadap batas umur pernikahan mereka lakukan karena demi melangsungkan perkawinan dengan legal dan demi mengurangi atau memulihkan harkat dan martabat (status sosial) yang terhina dimata masyarakat.

Data Forgery dalam Perkawinan Dini Perspektif Fungsionalisme Struktural

\section{Talcott Parsons}

Talcott Parsons adalah ahli sosiolog yang menerapkan teori Structural Functional di lingkungan orang berkeluarga. ${ }^{13}$ Teori ini lebih fokus dalam kesejajaran antara family life system dan social life system untuk memperoleh ketentraman hidup. Kemampuan setiap tindakan struktur dalam melaksanakan peran serta fungsi untuk menciptakan ketentraman dan kedamaian hidup bisa dipengaruhi oleh keadaan disekelilingnya. Parsons menyebut ini sebagai teori "tindakan voluntaristik". Actor didalamnya adalah manusia yang dipahami dapat bertindak lain sesuai dengan keadaan sosialnya yang dijalani waktu itu.

Bentuk tindakan voluntaristik Talcott Parsons: ${ }^{14}$

Gambar 1.1 Bentuk tindakan Voluntaristik dari para aktor

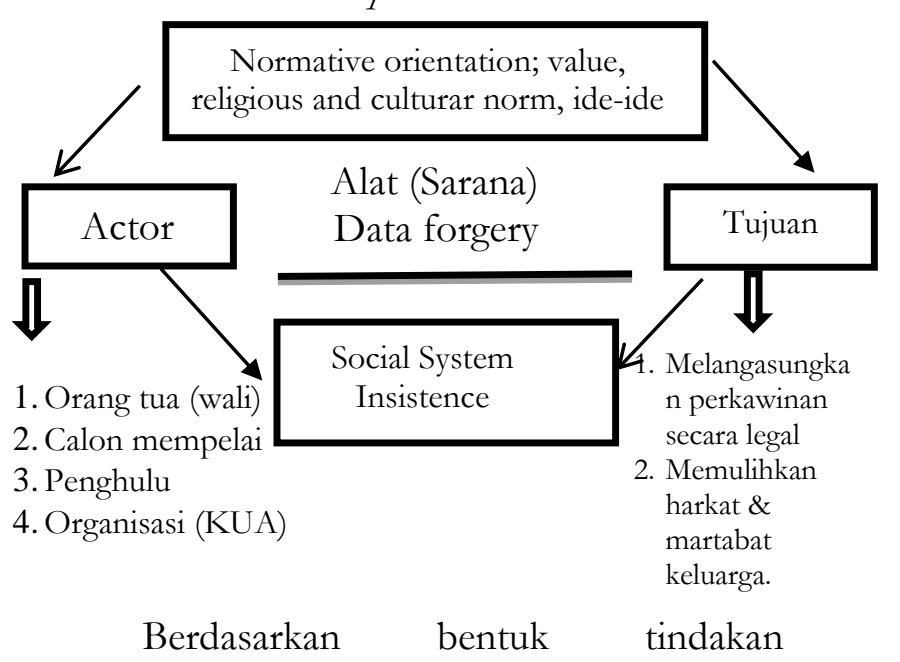

voluntaristic tersebut, orang yang memiliki tujuan adalah aktor. Aktor dari fenomena data forgery dalam perkawinan dini ini adalah keluarga atau orang yang terlibat dalam

\footnotetext{
${ }^{13}$ Herien Puspita, Konsep Dan Teori Keluarga, (Bogor : Fakultas Ekologi Manusia, 2013), 9

${ }^{14}$ Talcott Parsons, The Structure Of Social Action, Edisi Ke-II (New York : The Free Press, 1949), 81
} 


\section{ST. Sariroh}

perkawinan tersebut, baik itu calon mempelai, orangtua atau wali, penghulu, dan organisasi lembaga (sekelompok orang dalam suatu institusi). Menurut Talcott Parsons individu tidak akan bertindak tanpa tujuan yang jelas, karena tujuan adalah antisipasi subjektif suatu perubahan keadaan yang realisasinya diinginkan di masa depan sehingga diusahakan tercapai melalui tindakan tersebut. Dalam hal ini, si aktor tersebut untuk melancarkan tercapainya tujuan tersebut membutuhkan alat atau sarana, yang mana sarana tau alat tersebut dipilih sesuai dengan kondisi aktor pada saat itu. Sebagaimana dalam fenomena data forgery dalam perkawinan dini ini yang terjadi karena marriage by accident sehingga mereka melakukan pemalsuan data dengan cara menambahkan usia dalam surat keterangan perkawinan tersebut. perbuatan tersebut sangat dipengaruhi oleh cultural and social system yang melekat kuat dalam kehidupan kelompok masyarakat.

Dalan sistem tindakan ada beberapa faktor yang bisa mempengaruhi aktor (pelaku terkait pelaksanaan perkawinan dini dengan cara memalsukan data) dalam memilih alat atau cara untuk maraih keinginan.

Diantaranya:

\section{Sistem Budaya (Cultural System)}

Dalam sistem budaya ini yang sangat mendasar adalah tentang "arti" atau "sistem simbolik". Dalam chapter ini, Parsons sangat memperhatikan pada nilai yang dihayati bersama di lingkungan masyarakat tersebut baik dari faktor nilai-nila budaya, keyakinan yang dipatuhi oleh masyarakat. Sebagaimana budaya yang sangat melekat di masyarakat adalah budaya mengawinkan anaknya yang belum memenuhi syarat untuk melangsungkan pernikahan, masyarakat hanya memahami tentang batas sahnya pernikahan seseorang yaitu ketika mereka sudah aqil-baligh secara agama.

Masyarakat Madura selain itu juga sangat dikenal dengan prilaku ketaatan atau kepatuhan, ketundukan kepada sesuatu yang dipercayai sebagai suritauladan. Seperti kepatuhan terhadap ajaran agama yang diyakininya.

\section{Sistem Sosial (Social System)}

Struktur dan sistem sosial yang diterapkan oleh masyarakat Madura yaitu bahwa kemampuan setiap orang dalam sosial tidak bisa lepas dari status serta peran sosialnya (social state and rule). Dalam menjalani kegiatan sehari-hari di masyarakat, status tersebut perlu adanya pengakuan dari orang atau kelompok lain. Sehingga mendapat perlakuan jelek atau hinaan terhadap peran dan status sosialnya sama seperti halnya tada' aabjinah. hal tersebut dapat menumbuhkan rasa maloh. ${ }^{15}$

Pelecehan dan bentuk cemooh merendahkan martabat keluarga bisa

\footnotetext{
${ }^{15}$ A. Latief Wiyata, Mencari Madura, 23
} 
diakibatkan dari perbuatan tidak senonoh anggota keluarga seperti perbuatan anak-anak mereka yang melanggar norma-norma sosial, agama, dan hukum yang menjatuhkan dalam perbuatan zina. Perbuatan tersebut merupakan hal yang sangat dilarang dalam islam. Bagi orang madura yang dikenal dengan sikap ketaatannya terhadap ajaran agama. Lebih-lebih bagi orangtua, beban moral yang ditanggung dapat menimbulkan rasa malo atau tade' ajhinah karena adanya omongan-omongan atau sindiran jelek dari masyarakat bahkan dari sanak keluarga sendiri. Sebagai orang tua mereka merasa tidak berhasil mengajarkan anaknya dengan baik. Karena keadaan tersebut mereka bisa melakukan apa saja demi memperbaiki atau mengurangi beban moral demi menjaga hargadiri keluarganya. Seringkali tindakan perlawanan tersebut cenderung sangat keras bahkan bisa sampai terjadi embunuhan. Namun perlawanan yang dilakukan sesuai dengan celaan yang telah diterima.

Para aktor dalam fenomena data forgery dalam perkawinan ini mendapatkan tekanan kuat dari lingkungan sosial sehingga memperngaruhi perilakunya untuk melakukan pertentangan yaitu dengan cara mengawinkan anaknya sesegera mungkin walaupun harus melanggar hukum negara yang berlaku. Hal ini bertujuan agar proses perkawinan sah secara hukum bisa terlaksana dengan lancar tanpa ada kendala sedikitpun. Hal tersebut dilakukan agar anak yang akan dilahirkan kelak memiliki seorang ayah. Begitu juga dengan harkat dan martab keluarga akan dinilai semakin membaik dimata masyarakat.

Tekanan-tekanan yang mereka terima berupa cemooh atau hinaan dari lingkungan msyarakat ini memang sangat berpengaruh terhadap tingkah laku seseorang demi menjaga nama baik dan menutupi aib keluarga. Sehingga tidak mempunyai jalan lain kecuali melakukan pemalsuan data perkawinan agar anak yang belum memenuhi syarat usia perkawinan tetap bisa melangsungkan perkawinan dengan sah dan legal secara hukum.

Selain itu, penyebab utama adalah faktor perubahan sosial dilingkungan masyarakat seperti bentuk modernisasi yang sangat berpengaruh terhadap tingkah laku remaja saat ini. Dampak negatif yang ditimbulkan dari hal tersebut seperti tingkah laku dengan adanya alat elektronik (handphone, internet dan media sosial) mejadikan mereka lebih mudah berinteraksi dengan lingkungan luas seperti berhubungan dengan lawan jenis. Sehingga mereka dengan mudah melakukan hal-hal yang melanggar norma-norma sosial, agama dan hukum tanpa sepengetahuan orang tua yang mengakibatkan 


\section{ST. Sariroh}

mereka terjrumus dalam perbuatan yang dilarang agama yaitu perzinahan yang akhirnya hamil sebelum mendapatkan perkawinan yang sah.

Perilaku remaja pada dasarnya memang masih labih dan belum memiliki prinsip dan pendirian yang tetap. Sehingga sangat mudah pengaruh-pengaruh negatif merubah perilakukanya dintaranya pengaruh dari lingkungan sekitar seperti teman, televise, bahkan internet yang saat ini menguasai perubahan gelobal. Pantauan orangtua sulit untuk melihat perkembangan perilaku anak yang menyebabkan mereka terjerumus dalam pergaulan bebas.

\section{Sistem Kepribadian (Personality System)}

Kesatuan yang sangat dasar dibagian ini adalah individu itu sendiri yang menjadi aktor atau pelaku dari fenomena data forgery dalam perkawinan dini. Sistem kepribadian sangat berpengaruh terhadap tindakan dan perilaku pelaku, seperti tindakan orang tua yang melakukan pelanggaran terhadap aturan negara terkait pernikahan, hal itu karena ketidakpahaman terhadap aturan tersebut. Disisi lain karena tingkat pendidikannya hanya dijenjang sekolah dasar.

Sementara aktor pelaku penyebab utama fenomena ini adalah si anak dimana mereka melakukan tindakan pelanggaran terhadap norma agama atau aturan hukum yang menjadikan mereka terperosok pada perbuatan maksiat seperti berhubungan layaknya suami-ieteri dengan lawan jenis yang menyebabkan hamil sebelum mendapat gelar pernikahan yang sah. Selain itu minimnya pengetahuan agama menjadikan mereka tidak bisa berfikir secara luas terhadap dampak negatif setiap sesuatu yang dilakukan.

\section{Sistem Organisme Biologis (Biological Organism System)}

Aspek biologis manusia sejak lahir juga sangat berpengaruh terhadap perilakunya ketika sudah dewasa. Hal ini terjadi bisa disebabkan karena factor-faktor perilaku yang diterima dari lingkungan sekitarnya, seperti betuk perilaku dari kelurga sejak kecil, dan juga sifat bawaan yang dimiliki sejak lahir atau sifat turunan.

Dari berbagai faktor sistem tersebut, bisa diambil kesimpulan bahwa perilaku manusia, sebagai struktur terpenting dalam mewujudkan kesejahteraaan masyarakat bisa berubah sesuai dengan lingkungan yang mempengaruhi pada saat itu. Dalam hal fenomena data forgery dalam perkawinan dini sebab MBA (Marriage By Accident) yang menjadi faktor utama para orang tua, penghulu dan lembaga KUA berperilaku melanggar atusan hukum yaitu adanya tekanan kuat dari lingkungan sosial masyarakat. Orangtua mendapat penilaian buruk dari masyarakat bahkan disebagian tempat bisa dikucilkan. Hal ini menjadi penyebab kesulitan dalam kehidupan orang lain (kepercayaan buruk masyarakat akan 
An-Nisa' : Jurnal Kajian Perempuan \& Keislaman

Vol. 14, No. 2, Oktober 2021

p-ISSN : $2086-0749$

e-ISSN : 2654-4784

menyebabkan kemarau berkepanjangan). Bagi masyarakat Madura tindakan yang sifatnya melanggar norma agama dan budaya seperti perbuatan zina yang menyebabkan hamil sebelum menikah dipercayai menjadi penyebab datangnya bencana atau musibah dikehidupan masyarakat.

Dalam Kehidupan sosial sebagai suatu sistem membutuhkan adanya ketergantungan yang berdampak pada keseimbangan sosial. Adanya sistem yang tidak teratur karena minimnya kesadaran tentang saling kebergantungan satu sama lain. Seperti terjadinya data forgery dalam proses pelaksanaan perkawinan dini dikalangan masyarakat Madura yang disebabkan oleh pergaulan bebas anak muda sehingga terjerumus pada perbuatan terlarang yaitu zina. Dampak dari perilaku tersebut yang menyebabkan terjadinya ketidak seimbangan antara struktur sosial budaya di masyarakat dan struktur organisasi (lembaga) sehingga terjadinya suatu masalah.

Talcott Parsons memberikan syaratsyarat fungsi sistem yang harus terpenuhi Agar semua sistem bisa menjalankan fungsinya dengan baik. Selanjutnya akan dijelaskan lebih mendalam bagaimana struktur-struktur sistem sosial di masyarakat Madura dapat menciptakan kehidupan masyarakat yang stabil dan tentram, khususnya bagi anggota keluarga pelaku data forgery dalam perkawinan dini yaitu melalui empat syarat-syarat fungsi yang ditawarkan oleh Talcott Parsons yang disingkat dengan skema AGIL, sebagai berikut;

\section{Adaptasi (adaptation)}

Konsep adaptasi ini adalah kemampuan masyarakat untuk berinteraksi atau menyesuaikan diri dengan lingkungannya dan institusi sosial agar dapat terus bertahan dalam menghadapi situasi external yang tidak mendukung. ${ }^{16}$ Jika dikaitkan dengan fenomena data forgery dalam perkawinan dini ini, para aktor utama yang menyebabkan hamil diluar nikah tersebut harus dapat menyesuaikan diri dengan sistem sosial dilingkungan masyarakat.

Masyarakat Madura Selain dikenal dengan sikap kepatuhannya, dan ketundukan terhadap apa yang mereka yakini seperti terhadap ajaran agama yang diyakininya, mereka juga sangat menjunjung tinggi harga diri dalam kehidupannya. Hidup mereka tidak akan berarti jika harus menanggung maloh (malu) sebagaimana dalam pepatah kuno "ango'an apoteya tolang katembeng apoteya mata" (lebih baik meninggal terkubur dalam tanah daripada hidup menanggung rasa malu). ${ }^{17}$ Hinaan dan pelecehan terhadap harga diri yang mereka terima dari lingkugan sekitar

${ }^{16}$ Talcott Parsons, The Social system, 116

${ }^{17}$ A. Latief Wiyata, Mencari Madura, 17 


\section{ST. Sariroh}

samahalnya dengan hinaan terhadap kapasitasdan kemampuan diri mereka yang menimbulkan rasa maloh.

Jika mengalami perlakuan atau anggapan “tada' abjinah", mereka akan melakukan pertentang atau perlawanan sebagai upaya untuk mengembalikan harga diri mereka yang direndahkan.

Perilaku melawan dalam kasus data forgery dalam perkawinan dini ini yaitu dengan cara sesegera mungkin mengawinkan putrinya dengan pria yang menghamilinya. Mereka lakukan untuk melaksanakan perkawinan dengan segera walaupun dengan cara menyalahi peraturan perundan-undangan yang berlaku, seperti halnya menambahkan usia putra atau putrinya yang belum memenuhi syarat untuk melaksanakan pernikahan.

\section{Goal Attainment}

Dalam fenomena data forgery dalam perkawinan dini yang terjadi di Madura yaitu orang tua sebagai actor dalam kasus ini dan selaku orang yang memiliki tanggungjawab penuh terhadap anaknya bermaksud untuk menikahkan anaknya secara legal atau tercatatkan walaupun belum memenuhi syarat atau batas usia untuk melangsungkan menikah sebagaimana yang telah diatur dalam pasal 1 ayat (1) Undang-Undang tentang perkawinan No. 16 Tahun 2019 yang menyatakan bahwa ;
"Perkawinan banya diizinkean apabila pria dan wanita sudah mencapai umur 19 (sembilan belas) tabun."'s

Secara jelas peraturan tersebut mengharuskan bagi pasangan yang akan melangsungkan perkawinan sudah berusia 19 Tahun, namun jika belum memenuhi syarat batasan usia untuk menikah maka harus mengajukan dispensasi kawin ke Pengadilan Agama dengan beberapa alasan-alasan yang kuat. Namun kenyataannya para aktor atau pelaku perkawinan dini di Madura ini lebih memilih untuk mema;sukan atau menambahkan usia dalam buku nikah yang akan didapatkan bagi mempelai yang belum memenuhi syarat. Hal ini secara ekplisit dijelaskan dalam pasal 1 ayat 2 bahwa:

"Orang tua dari pibak pria dan/atau orang tua pihak wanita dapat meminta permohonan dispensasi kepada Pengadilan dengan alasan sangat mendesake disertai bukti-bukti pendukung yang cukup."19

Dalam kehidupan masyarakat Madura sistem sosial budaya yang secara empirik terjadi bertujuan untuk menjaga kehormatan kelurga, menjaga hubungan baik yang terjalin diantara mereka, dan juga menjaga tatakrama atau kesopanan. Kesopanan merupakan unsur sangat penting yang harus ditanamkan dalam diri untuk berperilaku dengan sesama. Walaupun banyak yang bahwa suku madura

${ }^{18}$ Undang-Undang No. 16 Tabun 2019 Tentang Perubahan Terhadap UU Perkawinan no. 1 tabun 1974, 2

${ }^{19}$ Undang-Undang No. 16 Tabun 2019 Tentang Perubahan Terbadap UU Perkawinan no. 1 tabun 1974, 3 
memiliki sifat kasar namun mereka sangat menjunjung tinggi sikap kesopanan. mereka tidak pernah membeda-bedakan antara miskin dan kaya, tampan dan cantik semuanya sama yangpaling penting yaitu nilai tatakrama yang dimilikinya.

Pada dasarnya, batas umur perkawinan dalam hukum Islam tidak diatur secara mutlak. Tidak adanya ketentuan agama tentang batas umur minimal dan maksimal untuk melangsungkan perkawinan diasumsikan memberi kelonggaran bagi manusia untuk mengaturnya. Dalam AlQur'an mengisyaratkan bahwa seseorang yang berniat untuk melangsungkan perkawinan adalah orang yang siap dan mampu baik lahir maupun batin.

Sebagian mufassir menafsirkan bahwa yang dimaksud orang yang layak yakni orang yang mampu secara spiritual dan mental untuk membina dan membangun rumah tangga dengan baik. ${ }^{20}$ Begitu pula dalam hadits Rasulullah SAW, memberi anjuran kepada para pemuda untuk melaksanakan perkawinan dengan syarat adanya kemampuan.

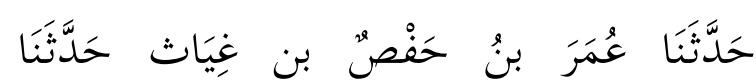

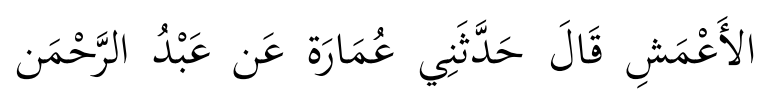

${ }^{20}$ M. Quraish Shihab, Tafsir al Misbah, Vol. IX (Jakarta: Lentera Hati, 2015). 335

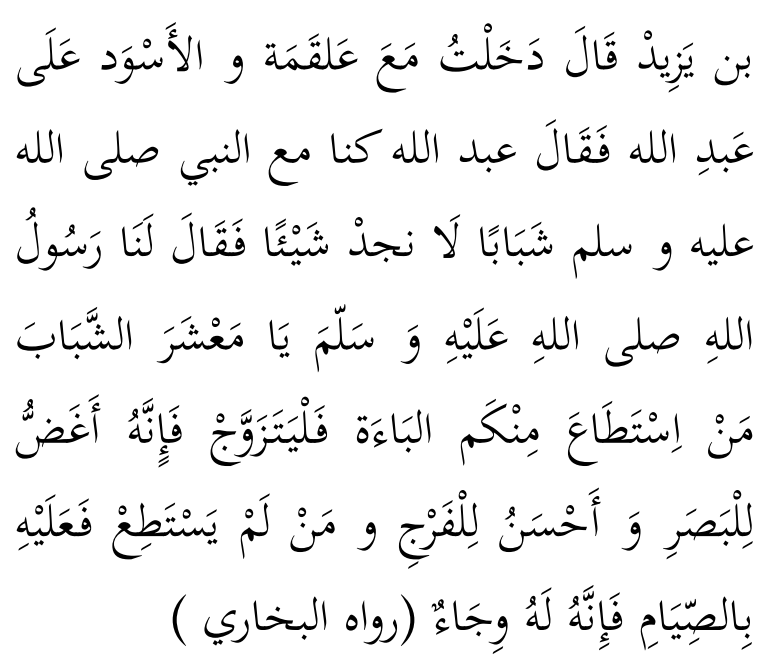

Artinya "Kami telah diceritakan dari Umar bin Hafs bin Ghiyats, telab menceritakan kepada kami dari ayabku (Hafs bin Ghiyats), telah menceritakan kepada kami dari al A'masy dia berkata : "Telah menceritakan kepadaku dari 'Umarah dari Abdurrahman bin Yazid, dia berkata: "Aku masuk bersama 'Alqamah dan al Aswad ke (rumah) Abdullah, dia berkata : "Ketika aku bersama Nabi SAW dan para pemuda dan kami tidak menemukan yang lain, Rasulullah SAW bersabda kepada kami: "Wahai para pemuda, barang siapa di antara kamu telah mampu berumah tangga, maka kawinlah, karena kawin dapat menundukean pandangan dan memelihara kemaluan. Dan barangsiapa belum mampu, maka bendaklah berpuasa, maka sesunggubnya yang demikian itu dapat mengendalikan hawa nafsu." (HR. Bukhari) ${ }^{21}$

${ }^{21}$ Abdullah Muhammad bin Ismail al Bukhari, Shabih al Bukhari, Juz V, (Beirut: Dar al-Kitab alIlmiyah, 1992).438. 


\section{ST. Sariroh}

Dalam Al-Qur'an dan Hadits secara tidak langsung mengisyaratkan bahwa kedewasaan dan kemampuan mental maupun spiritual sangat penting dalam membangun rumah tangga. Dalam fiqih islam orang dianggap dewasa ketika sudah baligh. Bagi pria yaitu telah berusia 15 tahun, atau telah mengalami mimpi basah. Sedangkan wanita ditandai dengan datangnya haid (menstruasi) yaitu minimal usia 9 tahun. $^{22}$ Tidak ada batasan yang pasti untuk boleh melangsungkan perkawinan dalam islam karena ukuran kedewasaan dan kemampuan setiap manusia berbeda-beda.

\section{Integration}

System soaisl buadaya yang terjadi dalam masyarakat Madura mengharuskan mereka untuk bisa mempertahankan dan menjaga hubungan baik dan tentram dengan strktur ungsi yang lain. Diantaranya menjaga hubungan baik dengan fungsi struktur organisasi (lembaga KUA) yang mana dalam fenomena ini lembaga tersebut memiliki kewenangan dalam memproses pelaksanaan perkawinan secara sah. Lembaga tersebut yang akan menyediakan dan memproses semua kegiatan dalam proses surat menyurat dalam perkawinan.

Pada kenyataaanya, kebiasaan system sosial yang berlaku di masyarakat Madura menjadi penyebab utama bagi para aktor

${ }^{22}$ Salim bin Samir al Hadhramy, Safinah an Najah, (Semarang: Dar Al-Abidin, tt). 15-16 dalam fenomena data forgery perkawinan dini untuk bertindak melanggar peraturan perundangan yang berlaku yaitu memalsukan data usia ketika dalam proses pengajuan pernikahan di KUA (Kantor Urusan Agama). Mereka bermaksud agar anak yang belum memenuhi syarat untuk melangsungkan perkawinan bisa melaksanakan perkawinan tanpa melalui proses permohonan izin dispensasi usia nikah ke Pengadilan Agama sebagaimana yang telah diatur dalam pasal 1 ayat 2 Undang-Undang No. 16 tahun 2019 tentang perkawinan.

\section{Latency}

System Latency ini berkaitan dengan penjagaan terhadap nilai-nilai atau pola-pola budaya dengan baik. Masyarakat harus bisa menjaga dan melestarikan nilai-nilai budaya atau kebiasaan baik. Kebiasaan baik ini mejadi bentuk keunikan dan keshususan yang dimiliki oleh masyarakat Madura.

Kekhususan itu diantaranya dari aspek kepatuhan, serta kepasrahan kepada keyakinan yang mereka ajari. Seperti kepatuhan mereka terhadap ajaran islam yang dipahaminya. Kepercayaan dan keyakinan ini adalah menjadi prinsip dalam menjalani kehidupannya, hal tersebut dapat terlihat dari cara berpakaian mereka sehari-hari yang dijadikan simbol keislaman diantaranya sampeer (kain panjang), kebaya', dan bburgo' (kerudung) untuk para wanita, saroong 
An-Nisa' : Jurnal Kajian Perempuan \& Keislaman

Vol. 14, No. 2, Oktober 2021

p-ISSN : $2086-0749$

e-ISSN : 2654-4784

(sarung), dan songko' (kopiah atau peci) bagi para pria khususnya di daerah pedesaan. ${ }^{23}$

Mereka sangat menjunjung tinggi harga diri dalam kehidupannya. kehidupnya tidak berguna jika mereka terbebani dengan rasa malooh (malu) seperti halnya dalam pepatah kuno "ango'an apoteyah tolang etembeng apoteyah mata" (lebih baik meninggal dunia terkubur dalam liang lahat daripada hidup dengan membawa beban rasa malu).. ${ }^{24}$

Dalam lingkungan sosial dan budaya di Madura sangat dikenal dengan keta'atan dan kepatuhannya. Seperti halnya ungkapan bhuppa', bhabbu', ghurub dan ratoh (bapak, ibu, guru dan pemimpin). maksudnya dalam kehidupan social dan budaya terdapat standard pedomam keta'atan kepada tokohtokoh penting secara hirarkis. ${ }^{25} \mathrm{Hal}$ itu merupakan ketentuan normatif yang melekat pada diri mereka sehingga akan memperoleh social and cultural punishment jika tidak dipatuhi.

\section{Simpulan}

Fungsionalisme struktural fenomena data surgery dalam perkawinan dini ini adalah 1). Fenomena perkawinan dini dilaksanakan oleh pasangan "sebelum usia 19 tahun ". Dengan cara menambahkan usia di identitas

${ }^{23}$ A. Latief Wiyata, Mencari Madura, 3

${ }^{24} \mathrm{~A}$. Latief Wiyata, Mencari Madura, 17

${ }^{25}$ Taufiqurrahman, Identitas Budaya Madura, (Pamekasan, Jurnal Karsa Vol XI No. 1, 2007), 3 perkawinanya sebab Marriage By Accident, karena menjadi tanggungan keluargal yang dapat menjadikan rasa maloh atau tade' ajhinah. 2). Fungsionalisme struktural data forgery dalam perkawinan dini; Adaptation; proses habituasi para aktor dengan sistem sosial di masyarakat adalah dengan cara memalsukan usia perkawinan. Goal Attainment; hal ini demi mendapatkan legalisasi hukum perkawinan dan meningkatkan harkat martabat keluarga menjadi lebih baik. Integration; tidak selarasnya fungsi sistem sosial dan struktur lembaga di KUA. Latency; Masyarakat harus memelihara pola-pola tradisi sebaik mungkin, seperti penghormatan dan kepatuhan terhadap harga diri keluarga maupun orang lain.

\section{Daftar Pustaka}

Al-Bukhari. Abdullah Muhammad bin Ismail. Shabih al Bukhari. Juz V, Beirut: Dar al-Kitab al-Ilmiyah, 1992.

Al-Hadhramy, Salim bin Samir. Safinah an Najah. Semarang : Dar Al-Abidin, tt.

Bawono. Yudho dan Suryanto. "Does Early Marriage Make Women Happy? a Phenomenological Finding from Madurese Women". Journal of Educational, Health and Community Psychology Vol 8, No 1, (2019). 


\section{ST. Sariroh}

Bawono, Yudho. "Low Education and Erly Marriage in Madura: Literature Review". The Journal of Educational Development, 7 (3) (2019).

Haper, Donald W. Structure Functionalism Grand Theory or Methodology. London: Article School Of Management, Leicester University, 2011.

Nurdin, Ismail dan Sri Hartati. Metode Penelitian Sosial. Surabaya: Media Sahabat Cendekia, 2019.

Jamilah dan Roudlotun. "Fenomena Pernikahan Anak Di Suemnep Madura". Jurnal Harkat: Media Dan Komunikasi Gender 15 (1) (2019)

Mila. Ainur Rofika dan Iswari Hariastuti. "Faktor Sosial Budaya yang Mempengaruhi Terjadinya Pernikahan pada Usia Anak di Kabupaten Sumenep". Jurnal Promkes: The Indonesian Journal of Health Promotion and Health Education Vol. 8 No. 1 (2020).

Parsons. Talcott. The Social system. Edisi Ke-II New York : The Free Press, 1951.

Parsons. Talcott. The Structure Of Social Action. Edisi Ke-II. New York : The Free Press, 1949.

Puspita. Herien. Konsep Dan Teori Keluarga. Bogor : Fakultas Ekologi Manusia, 2013.

Quran Surat An-Nuur ayat 32

Rusli. "The Role of Family in Preventing Social Conflict in Society from Islamic
Perspectives". Jurnal Hunafa: Studia Islamika, Volume 17, Number 1, (2020).

Sepri Ayu. "Analisis Pernikahan Dini, Nikah Sirri, Poligami, dan TKW di Madura”. http://ayuflow.blogspot.co.id/2015/12 /analisis-pernikahan-dini-nikahsirri.html di akses pada tanggal 02 Februari 2017, Pukul 12:05

Shihab. M. Quraish. Tafsir al Misbah. Vol. IX. Jakarta: Lentera Hati, 2015.

St. Sariroh. 'Perkawinan Dini Perspektif Fungsionalisme Struktural Talcoot Parsons: studi kasus di Desa Poreh Kecamatan Lenteng kabupaen Sumenep'. Thesis. UIN-Malang: 2017.

Sugiyono. Metode Penelitian Pendidikan Kuantitatif, Kualitatif dan $\mathrm{R}$ dan $\mathrm{D}$. Bandung: Alfa Beta, 2013.

Taufiqurrahman. "Identitas Budaya Madura", Pamekasan, Jurnal Karsa Vol XI No. 1, 2007.

Undang-Undang R.I Nomor 1 Tahun 1974 Tentang Perkawinan Dan Kompilasi Hukum Islam, Bandung: Citra Umbara, 2012

Wiyata. A. Latief. Mencari Madura. Jakarta : Bidik-Phronesis Pu Publishing, 2013. 